\title{
Long-term effects of moderate physical exercise during early childhood on insulin sensitivity in rats during adulthood
}

\author{
Rodrigo Martins PEREIRA* \\ Vitor R. MUÑOZ* \\ Chadi P. ANARUMA* \\ Rafael Calais GASPAR* \\ Rodrigo S. GASPAR ${ }^{*}$ \\ Eduardo R. ROPELLE* \\ Dennys CINTRA* \\ Adelino da SILVA ${ }^{* *}$ \\ José Rodrigo PAULI* \\ Leandro Pereira de MOURA*
}

*Sport Science Department, School of Applied Science of State University of Campinas, Limeira, $\mathrm{SP}$ Brazil.

**School of Physical Education and Sport of Ribeirão Preto, University of São Paulo, Ribeirão Preto, SP, Brazil.

\begin{abstract}
It is of great importance to investigate the effects of physical exercise for metabolic health when performed in early life, and what the adulthood response would be. The aim of this study is to analyse the effects of moderate intensity physical exercise protocol during childhood on the adipose tissue and insulin sensitivity of rats during adulthood. Twenty weaned Wistar ( 28 days old) were divided into control and trained groups. The Control Group was kept sedentary, and the Trained group was submitted to swimming exercise at $80 \%$ of the anaerobic threshold (determined by the lactate minimum test) for 1 hour/day, 5 days/week from 28 to 90 days of age. At the end of the experiment, the body weight, adiposity (adipose tissue weight), insulin sensitivity, glycemia, insulinemia, pancreatic insulin, lipogenic activity in mesenteric fat, lipogenic activity and glycogen store in gastrocnemius and glucose uptake by soleus were analyzed. Trained group showed lower body weight gain, fat acumulation, lipid synthesis, glycemia, insulinemia and pancreatic insulin level. Kitt, HOMA-IR, glycogen store in gastrocnemius and glucose uptake by soleus were higher in this group. Therefore, we conclude that the moderate physical exercise performed during childhood can contribute to the reduction of body fat and insulin resistance during adulthood in Wistar rats.
\end{abstract}

Palavras-chave: Moderate Exercise; Weaned Rats; Insulin Resistance; Overweight; Obesity; Diabetes.

\section{Introduction}

The prevalence of overweight and obesity has been growing over the years, and it is estimated that in 2030 more than half the world's population will be obese ${ }^{1}$. Obesity is considered one of the biggest public health problems in the world, having as main feature high levels of fasting insulin in response to glucose consumption, phenomenon known as insulin resistance (IR) ${ }^{2}$. Therefore, a number of studies demonstrate that its development is influenced by behavioral, genetic and environmental factors ${ }^{3}$.

In this context, regular physical exercise is considered an important strategy for the treatment and prevention of obesity and IR, promoting reduction in fat mass and increased energy expenditure ${ }^{4}$. These benefits provided by the exercise occur by its ability to modulate various proteins involved in the insulin signaling pathway in key tissues of glucose homeostasis control, such as skeletal muscle, liver and hypothalamus 5 .

Although the beginning of physical exercise is proposed from youth ${ }^{6}$, it is still unclear what would be the metabolic benefits in adulthood from this practice. In this sense, few studies using rodents have shown that voluntary practice exercise after weaning promotes a number of benefits related to metabolism, such as lower levels of circulating leptin ${ }^{7}$, reduction of body fat and increase in the amount of brown adipose tissue ${ }^{8}$. Also, 
the increase of leptin sensitivity and resistance to the development of obesity can remain for weeks, even after the cessation of exercise practice ${ }^{9}$. However, these studies did not investigate the effects of systematic practice exercises, controlling the training variables such as individual volume and intensity of effort.

In this sense, it is of great importance to investigate the effects of exercise for metabolic health when it is performed in early life, and what the adulthood response would be. Studies on this field can provide

\section{Method}

\section{Animals}

Twenty weaned Wistar rats were used at 21 days of age at the beginning of the experiment. They came from central vivarium of the State University of São Paulo (UNESP, Botucatu/SP - Brazil). The animals were allocated in polyethylene cages, measuring 37 x 31 x $16 \mathrm{~cm}$ (five mice per cage) and maintained at a temperature of $21^{\circ} \mathrm{C}$. The rats remained in a room with a photoperiod of $12 \mathrm{~h}$ light/dark and were fed, ad libitum, with balanced standard Purina food and water. From 28 to 90 days of age, the animals were divided into two groups: Control $(\mathrm{n}=10)$ that remained sedentary throughout the experiment and Trained $(n=10)$ that were subject to a swimming training protocol over the entire experiment. In order to establish an initial homogeneity between groups, different variables such as weight, glycemia, insulinemia, triglycerides concentrations, and lipogenic activity were measured at the beginning of the experiment ( 28 days). All animal experiments were performed in accordance with the Brazilian law for scientific use of animals (law 11.794, October 8, 2008). The protocols were approved by the Ethics Committee on Animal Use (CEUA) from the Institute of Biosciences of UNESP - Rio Claro (Protocol: 4573/2010).

\section{Adaptation to the water environment}

All trained animals were adapted to the water environment that consisted of keeping the animals in shallow water for 3 days for 10, 20 and $30 \mathrm{~min} /$ day respectively at a temperature of $31 \pm 1^{\circ} \mathrm{C}$ to minimize the stress experienced. a better knowledge about the exercise benefits in early life and encourage the controlled training programs participation. This strategy can be an important way to combat obesity and IR, since it is proposed that physically active subjects at early stages of life tend to maintain that level of activity when adults ${ }^{10}$. Therefore, the present study aimed to analyze the long-term effects of a moderate intensity physical exercise protocol during childhood on the adipose tissue and insulin sensitivity of rats during adulthood.

\section{Determination of anaerobic threshold through lactate minimum test}

The moderate physical exercise was determined according to MourA et al. ${ }^{11}$. In summary, the lactate minimum test (LMT) was performed at 28, 50 and 70 days of age for determination of the anaerobic threshold in the trained animals, as proposed for humans ${ }^{12}$ and modified for rats ${ }^{11}$. For a better load control, this test was performed at different times throughout the experiment $(28,50$ and 70 days old). For the hyperlactacidemia induction, the animals were placed individually in tanks $(100 \times 80 \times 80 \mathrm{~cm})$ containing water at $31 \pm 1^{\circ} \mathrm{C}$, supporting overloads according to body weight $(20 \%$ at 28 days, $13 \%$ at 50 and 70 days old) and swam for 30 seconds. After this sub-maximal effort, the rats rested for 30 seconds. After that, they were then allowed to swim again with the same overloads until exhaustion. After a resting period $(12 \mathrm{~min}$ at 28 days of age and $9 \mathrm{~min}$ at 50 and 70 days of age), blood samples were collected by cutting the end of the tail to determine lactate concentration, and the animals began a swimming exercise with intensities progressively higher ${ }^{11}$. The determination of blood lactate concentrations was performed by the enzymatic method ${ }^{13}$.

\section{Training protocol}

From the weaning age to adulthood (28 to 90 days of age), the trained animals were submitted to swimming exercise in the same controlled individual tanks 1 hour per day, five days per week, supporting a overload of lead tied to the thorax, equivalent to $80 \%$ of individual AT, previously identified by the result of LMT. 


\section{Insulin tolerance test (ITT)}

At the beginning and at the end of the experiment (28 and 90 days of age), rats were submitted to an insulin tolerance test (ITT). The test was performed with fed and rested animals for 24 hours. The first blood sample was taken from the tail vein (time 0 ). Next, an insulin solution dose of $1 \mathrm{U} / \mathrm{Kg}$ of body weight was injected intraperitoneally. Blood samples were collected after 4, 8, 12 and 16 minutes post insulin injection with heparinized and calibrated capillaries $(25 \mu \mathrm{L})$ in order to determine the glucose concentrations through the glucose oxidase method (commercial kits - Laborlab ${ }^{\circledast}$ ). A single cut on the end of the tail was enough to collect all blood samples. The results were analysed by calculating the removal rate of serum glucose (Kitt) and applying the formula $(0.0693 / \mathrm{t} 1 / 2) \times 100$ and expressed in $\% / \mathrm{min}^{14}$. The removal of blood glucose $(\mathrm{t} 1 / 2)$ was calculated by the analysis curve of the minimum squares of the levels of blood glucose in the decay times after administration of insulin ${ }^{15}$ using Microsoft Excel ${ }^{\oplus} 2013$ software.

\section{Obtaining the biological material}

\section{Blood and Pancreas}

Seventy two hours after the last exercise session and forty eight hours after the last "in vivo" evaluation, fed animals were sacrificed with $\mathrm{CO}_{2}$ anaesthesia, and the blood was collected for serum separation and measurement of glucose (Laborlab ${ }^{\odot}$ ) and insulin by radioimmunoassay ${ }^{16}$ for determining the HOMA index (Homeostasis Model Assessment) according to Matthews et al. ${ }^{17}$. The entire pancreas was excised, weighed and macerated to determine insulin concentration also through radioimmunoassay ${ }^{16,18}$.

\section{Gastrocnemius muscle}

The gastrocnemius muscle was excised for determination of the intramuscular triglycerides concentration (using commercial kit Laborlab ${ }^{\circledast}$ ) at the beginning and at the end of the experiment ( 28 and 90 days of age) by enzymatic-spectrophotometric method according to the manufacturer's recommendation. A separate batch of animals ( $\mathrm{n}=6$ animals/group) was sacrificed 60 minutes after receiving intraperitoneal administration of tritiated water $\left(3 \mathrm{mCi} 3 \mathrm{H}_{2} \mathrm{O}\right)$. Aliquots of gastrocnemius muscle tissue were extracted and weighed to determine the rate of lipogenesis, as previously described ${ }^{19}$. The rate of lipid synthesis was expressed as micromol $(\mu \mathrm{mol})$ of $3 \mathrm{H}_{2} \mathrm{O}$ incorporated into lipids per hour per gram of tissue. Furthermore, at 90 days of age the concentration of gastrocnemius muscle glycogen was investigated ${ }^{20,21}$.

\section{Soleus muscle analyses}

After sacrifice, the soleus was removed and slices weighing between 25 and $35 \mathrm{mg}$ were subjected to incubation previously described ${ }^{22}$, modified for the test of glucose uptake. In summary, the slices were placed in KrebsRinger bicarbonate buffer, supplemented with glucose $(5,5$ $\mathrm{mM})$, containing [U-14C] glucose $(0,5 \mathrm{mCi} / \mathrm{mL}),[3 \mathrm{H}+]$ 2-deoxiglicose $(0,515 \mu \mathrm{Ci} / \mathrm{mL})$ and insulin $(100 \mu \mathrm{U} / \mathrm{mL})$ in vial glass for 90 minutes, and continuous gassing with $\mathrm{O}_{2}$ $/ \mathrm{CO}_{2}(95 \% / 5 \%)$ under constant stirring in a water bath $\left(37^{\circ} \mathrm{C}\right)$. The released $\mathrm{CO}_{2}$ was captured by hyamine $10 \mathrm{x}$, placed in glass apparatus inserted in the above mentioned vial. Glucose uptakewas assessed using the 2-deoxyglucose (2-DG) as marker, and the incorporation of $14 \mathrm{C}$ in the glycogen (synthesis) by measuring the radioactivity of the $3 \mathrm{H}$ of $2-\mathrm{DG}$ and glucose $14 \mathrm{C}$ respectively. The measurement of the amount of oxidized glucose was performed by radioactivity of $14 \mathrm{C}$ in hyamine. The radioactive lactate released into the incubation medium was determined by separation of metabolites in the ion exchange column (Dowex-2, Sigma).

\section{Adipose tissue analyses}

At the beginning and at the end of the experiment (28 and 90 days of age), the adipose tissue from different regions (subcutaneous, mesenteric, retroperitoneal and epididymal) was removed according to the description of $\mathrm{CINTI}^{23}$ for total weighing and determination of the triglyceride concentrations through enzymatic-spectrophotometric by glycerol phosphate (using commercial kit - Laborlab ${ }^{\oplus}$ ). A batch of animals ( $\mathrm{n}=6$ animals/group) was separated and the aliquots of mesenteric adipose tissue were extracted and weighed 60 minutes after receiving intraperitoneal administration of tritiated water $(3 \mathrm{mCi} 3 \mathrm{H} 2 \mathrm{O})$ to determine the rate of lipogenesis as previously described ${ }^{19}$. The amount of tritium incorporated was assessed in the adipose tissue $60 \mathrm{~min}$ after $3 \mathrm{H}_{2} \mathrm{O}$ administration. The rate of lipid synthesis was expressed as micromol of $3 \mathrm{H} 2 \mathrm{O}$ incorporated into lipids per hour, per gram of tissue.

\section{Statistics}

Results were expressed as mean \pm standard deviation. The student t-test for independent samples was used to compare the difference in means between the beginning and the end of the experiment for the trained and the control groups. The predetermined level of significance was $\mathrm{p}<0.05$. 


\section{Results}

At baseline, there was no difference in the physiological profile of both groups (TABLE 1).

At the end of the experiment, the rats from the trained group had a significantly lower body weight gain and a higher insulin sensitivity when they were compared to the animals from the control group (FIGURES 1A and 1B). Moreover, the analysis of adipose tissue showed a significant reduction in fat mass in all regions analysed: mesenteric, subcutaneous, retroperitoneal and epididymal (FIGURES 2A-D). The analysis of lipogenic activity in the mesenteric region showed that the animals submitted to exercise had lower lipid synthesis (FIGURE 2E).

TABLE 1 - Physiological profile at the beginning of the experiment.

\begin{tabular}{lcc}
\hline & Control & Trained \\
\hline \multicolumn{2}{c}{ In vivo } \\
Weight $(\mathrm{g})$ & $97,45 \pm 15,42$ & $95,20 \pm 13,32$ \\
Kitt $\left(\% . \mathrm{min}^{-1}\right)$ & $2,77 \pm 1,42$ & $2,48 \pm 0,83$ \\
& \multicolumn{2}{c}{ Post mortem } \\
& \multicolumn{2}{c}{$138,73 \pm 19,55$} \\
Glycemia $(\mathrm{mg} / \mathrm{dL})$ & $126,96 \pm 13,48$ & $0,21 \pm 0,10$ \\
Insulinemia $(\mathrm{ng} / \mathrm{mL})$ & $0,21 \pm 0,21$ & $520,76 \pm 210,71$
\end{tabular}

Triglycerides concentration $(\mathrm{mg} / \mathrm{g})$ :

Gastrocnemius muscle

Mesenteric adipose tissue

Epididymal adipose tissue

Subcutaneous adipose tissue

Retroperitoneal adipose tissue

$\begin{array}{rr}0,32 \pm 0,20 & 0,30 \pm 0,11 \\ 5,99 \pm 0,83 & 5,90 \pm 1,33 \\ 3,76 \pm 1,89 & 4,01 \pm 1,06 \\ 14,80 \pm 3,60 & 14,06 \pm 2,72 \\ 13,84 \pm 11,06 & 9,95 \pm 6,55\end{array}$

$1621,64 \pm 261,31$

$1586,10 \pm 123,01$

$882,52 \pm 235,05$

$882,52 \pm 235,05$

$1032,85 \pm 151,89$

Lipogenic activity $\left(\mu \mathrm{mol}\right.$ of $3 \mathrm{H}_{2} \mathrm{O}$ incorporated/h.g):

Gastrocnemius muscle

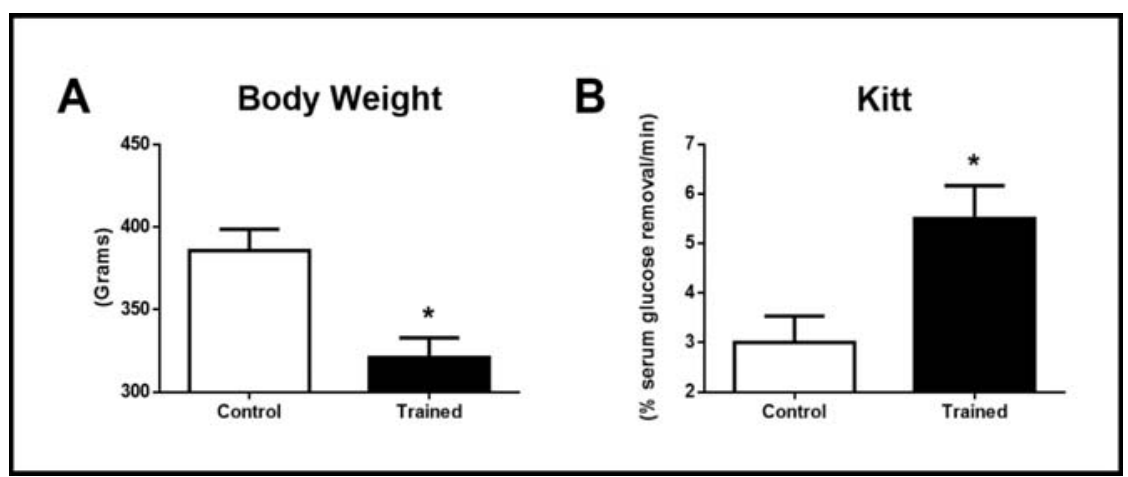

FIGURE 1 - Body weight (A) and serum glucose removal rate (Kitt) (B) in the control and trained groups at the end of the experiment (90 days of age). * $\mathrm{p}<0.05$. 

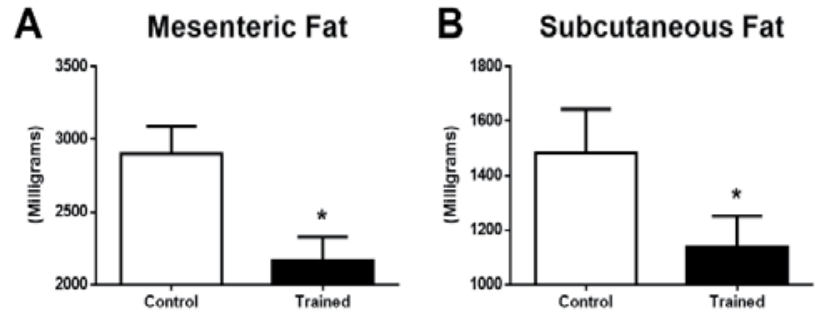

\section{E Lipogenic Activity in Mesenteric Fat}

C Retroperitoneal Fat
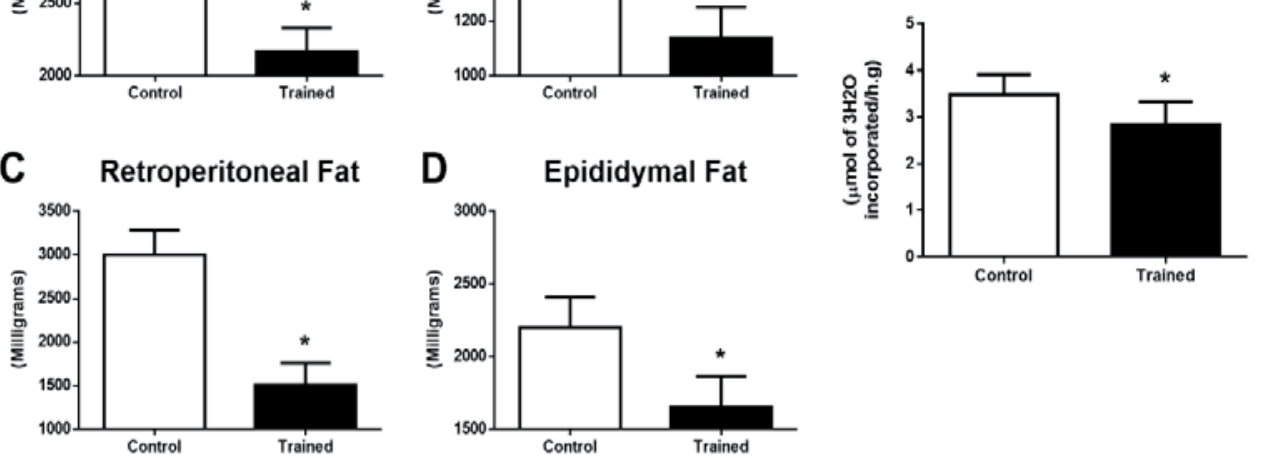

FIGURE 2 - Adipose tissue in different regions analysed: mesenteric (A), subcutaneous (B), retroperitoneal (C) and epididymal (D), and lipogenic activity in mesenteric fat (E) in the control and trained groups at the end of the experiment. ${ }^{*} \mathrm{p}<0.05$.

The blood collected to determine the serum glucose and insulin showed that physical training reduced glucose and insulin levels, even at the serum and pancreatic levels, resulting in an increase in the HOMA index (FIGURES 3A-D).

The lipidic and glucose profile in the gastrocnemius muscle was determined. Although physical training was not effective in changing the lipogenic activity (tritium incorporated) or triglyceride concentrations, it was possible to observe an increase of glycogen storage in this muscle (FIGURES 4A-C). Furthermore, the glucose uptake by the soleus muscle was increased in the trained animals as compared to the untrained group (FIGURE 4D).

\section{A}

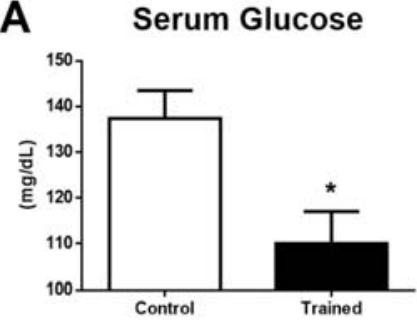

C

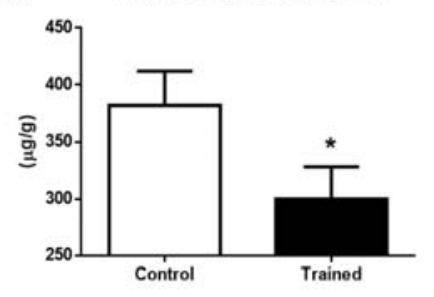

B Serum Insulin

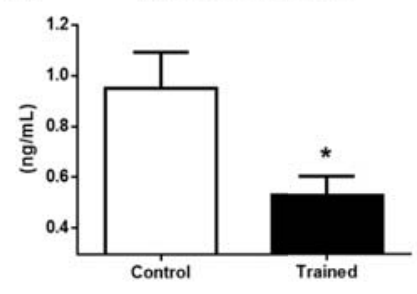

D

HOMA

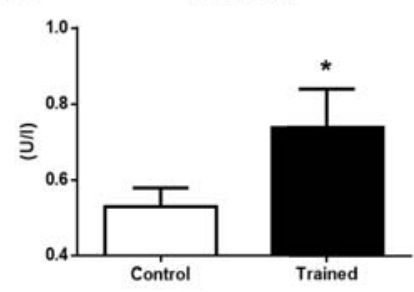

FIGURE 3 - Serum glucose (A), serum insulin (B), pancreatic insulin production (C), and HOMA index (D) in the control and trained groups at the end of the experiment. ${ }^{*} \mathrm{p} \leq 0.05$. 


\section{A Lipogenic Activity \\ A in Gastrocnemius}

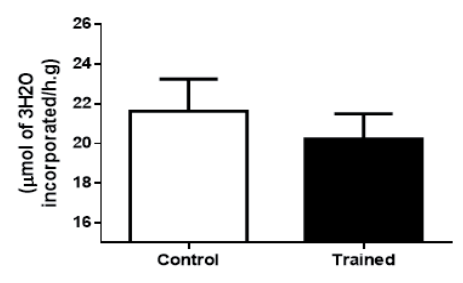

C Gastrocnemius

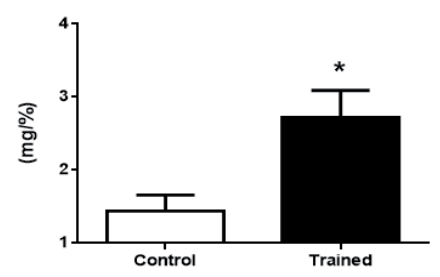

B

\section{Triglyceride Concentration in Gastrocnemius}

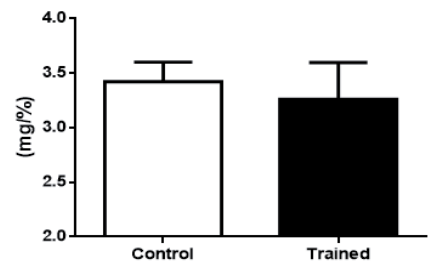

D Glucose Uptake in Soleus

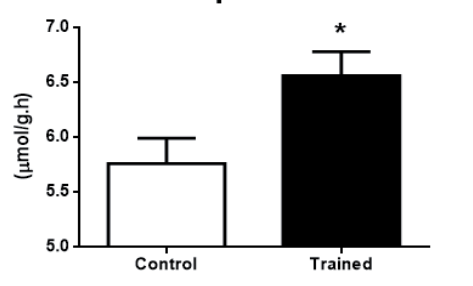

FIGURE 4 - Lipogenic activity in the gastrocnemius (A), triglyceride concentration in the gastrocnemius (B), glycogen storage in the gatrocnemius (C) and glucose uptake in the soleus (D) in the control and trained groups at the end of the experiment. ${ }^{*} \mathrm{p}<0.05$.

\section{Discussion}

Physical inactivity is considered one of the main causes of obesity. Since this disease is growing alarmingly, studies related to the prevention and / or treatment are of paramount importance. The present study aimed to investigate the effects of moderate exercise in adult mice when it was started in the childhood, on parameters related to obesity and IR. Thus, we observed positive changes in body composition of exercised animals compared to sedentary, such as less weight and amount of fat tissues, and a better response to insulin.

In this study, the physical training was able to reduce the body weight gain (FIGURE 1A) and, consequently, the fats stocks in all regions analyzed (mesenteric, epididymal, subcutaneous and retroperitoneal) (FIGURE 2A-D), and through a more sensitive analysis of fat synthesis in the mesenteric region, the lipogenic activity, we observed that the animals submitted to exercise had lower lipid synthesis (FIGURE 2E). The smaller gain in fat mass by trained group can be attributed to the fact that the exercise can activate the hormone sensitive lipase (HSL), increasing lipolysis and thus providing energy substrate for the activity performed ${ }^{24}$. Another factor that may have contributed to lower fat mass accumulation was the decrease in insulin concentrations, hormone that directly participates of lipogenesis ${ }^{25}$. According to the our findings, the fat mass reduction contributed to improvement in carbohydrate metabolism and generated favorable environment for better insulin sensitivity to peripheral tissues as shown by ITT (FIGURE 1B) and analysis of the HOMA index (FIGURE 3D).

The IR, when untreated, generates a hyperinsulinemia state and thus can trigger the failure of the pancreatic beta cells ${ }^{26}$. At the end of this experiment, when blood glucose, serum insulin, pancreatic insulin and HOMA index were analyzed, it was seen that the sedentary lifestyle makes that a state similar to IR and prediabetes was developed in the control group (FIGURE 3A-D). It is already established in the literature that the aging associated to physical inactivity can collaborate in the development of IR, providing greater gain of fat mass and lean mass reduction ${ }^{27}$. Thus, the physical inactivity in childhood, ally with the natural aging process, can be a determining factor for metabolic health. Therefore, regular physical exercise has been widely indicated for the prevention and/or 
treatment of this condition ${ }^{28,29}$, since the practice of exercises besides to increasing energy expenditure, elevate interleukin-6 (IL-6) levels, that when coming from the muscle contraction is able to minimize the inflammatory disorders caused by adipose tissue excess, from the peripheral levels until the central ${ }^{30}$. In addition, physical exercise contributes to better signaling of proteins involved in the metabolism of carbohydrates and lipids, moreover muscle contraction also has a positive effect on glucose uptake independently of insulin ${ }^{31,32}$.

In this study, when the gastrocnemius muscle was analyzed, no change in lipogenic activity and triglyceride concentration was found in the $T$ group (FIGURE 4A-B). It allows us to conclude that the action of insulin has been improved in this tissue, since even with a lower concentration of this hormone, the group maintained its lipogenic activity and its lipid reserves unchanged. However, the body weight of trained animals and all portions of fats were lower (FIGURE $1 \mathrm{~A}$ and 2A-D). Thus, we believe that there is also a greater capacity for mobilization and oxidation of fatty acids, which reflects an improved overall metabolic health, since there is evidences that muscle ability to oxidize fatty acids is an important regulator of insulin sensitivity, and this capacity is impaired by physical inactivity ${ }^{33}$.

During long physical exercise session, glycogen is the main muscle energy reserves ${ }^{34}$, providing glucose to the cells. The energy from glucose is an energy provided quickly, so its use is directly proportional to the intensity of the exercise ${ }^{35}$. The depletion of glycogen is widely used by athletes, once that after their depletion a state called glycogen overcompensation is installed, allowing the athlete to higher accumulation over basal levels, thus providing a better performance in tests using this energetic substrate ${ }^{36}$. In the present study, animals were exercised for 1 hour per day in moderate intensity. As expected, an increase in muscle glycogen levels in trained animals was observed (FIGURE 4C), as well as a greater glucose uptake by the soleus muscle (FIGURE 4D). Right after the end of the exercise protocol, muscle slices were incubated with insulin and glucose at baseline levels, revealing that even without a higher availability of glucose after depletion, there is a greater uptake of this substrate as a consequence of exercise.

The knowledge of the exercise intensity to be worked also shown to be extremely important. There are several studies that showed different responses to different exercise intensities ${ }^{37-39}$, therefore when compared to other variables such as weekly frequency and session volume, the intensity seems to be more relevant to the improvement of $\operatorname{IR}^{40}$. In this context, other studies also carried out aiming to investigate the benefits offered by exercise when started soon after weaning rodents ${ }^{7-9}$. However, these studies only provided to the animals access to the running wheel, and the effects observed by the authors related only to the spontaneous practice of exercises. Contrary to that found in our study, Acosta and colleagues found no significant reduction in body mass of animals exposed to the running wheel ${ }^{7}$. In another study, Schroeder and colleagues found no difference in the amount of retroperitoneal and epididymal fat in rats ${ }^{8}$. Thus, our study shows up as the first in the literature to demonstrate that moderate physical exercise performed since childhood, with controlled exercise intensity, can promote consistent improvement in body fat during adulthood, with this improvement reflecting in a better glycemic control and less production of insulin by the pancreas.

In summary, we found that moderate physical exercise performed during childhood can be an effective strategy to prevent body fat accummulation and insulin resistance during adulthood life.

\section{Conflict of Interest}

Authors declare no conflict of interest.

\section{Acknowledgements}

The authors would like to thank FAPESP (\#2015/07199-2 and \#2016/12569-6), CNPq, CAPES and FAEPEX, for their indispensable support. 


\section{Resumo}

Efeitos do exercício físico crônico moderado após o desmame na sensibilidade à insulina em ratos durante a fase adulta

É de grande importância a investigação dos efeitos do exercício para a saúde metabólica quando realizado no início da vida, e quais seriam as respostas durante a fase adulta. 0 objetivo desse estudo é analisar os efeitos do exercício físico de intensidade moderada durante a infância na adiposidade e sensibilidade à insulina de ratos durante a fase adulta. Vinte ratos Wistar desmamados de 28 dias de vida foram divididos em grupos Controle e Treinado. 0 grupo Controle permaneceu sedentário, enquanto o grupo Treinado realizou exercício de natação a $80 \%$ do limiar anaeróbio (determinado pelo teste de lactato mínimo) por 1 hora/dia, 5dias/ semana do $28^{\circ}$ até $090^{\circ}$ dia de vida. No fim do experimento, a massa corporal, adiposidade, sensibilidade à insulina, glicemia, insulinemia, insulina pancreática, atividade lipogênica do tecido adiposo mesentérico, atividade lipogênica e estoques de glicogênio no músculo gastrocnêmio e captação de glicose pelo músculo sóleo foram analizadas. 0 grupo Treinado apresentou menor ganho de massa corporal, acúmulo de gordura, síntese de lipídios, glicemia, insulinemia e insulina pancreática. Kitt, HOMA-IR, estoques de glicogênio no gastrocnêmio e captação de glicose pelo sóleo foram maiores nesse grupo. Portanto, concluímos que o exercício físico moderado realizado durante a infância pode contribuir para a redução da adiposidade corporal e resistência à insulina durante a fase adulta em ratos Wistar.

Palavras-chave: Exercício Moderado; Ratos Desmamados; Resistência à Insulina; Sobrepeso; Obesidade; Diabetes.

\section{References}

1. Finkelstein EA, Khavjou OA, Thompson H, Trogdon JG, Pan L, Sherry B, et al. Obesity and severe obesity forecasts through 2030. Am J Prev Med. Elsevier Inc.; 2012 Jun;42(6):563-70.

2. Kopelman P. Health risks associated with overweight and obesity. Obes Rev. 2007 Mar;8 Suppl 1(SUPPL. 1):13-7.

3. McAllister EJ, Dhurandhar N V, Keith SW, Aronne LJ, Barger J, Baskin M, et al. Ten putative contributors to the obesity epidemic. Crit Rev Food Sci Nutr. 2009 Nov;49(10):868-913.

4. Church T. Exercise in obesity, metabolic syndrome, and diabetes. Prog Cardiovasc Dis. Elsevier Inc.; 2011;53(6):412-8.

5. Musi N, Goodyear LJ. Insulin resistance and improvements in signal transduction. Endocrine. 2006 Feb;29(1):73-80.

6. Strong WB, Malina RM, Blimkie CJR, Daniels SR, Dishman RK, Gutin B, et al. Evidence based physical activity for school-age youth. J Pediatr. 2005 Jun;146(6):732-7.

7. Acosta W, Meek TH, Schutz H, Dlugosz EM, Vu KT, Garland T. Effects of early-onset voluntary exercise on adult physical activity and associated phenotypes in mice. Physiol Behav. Elsevier B.V.; 2015 Oct 1;149:279-86.

8. Schroeder M, Shbiro L, Gelber V, Weller A. Post-weaning voluntary exercise exerts long-term moderation of adiposity in males but not in females in an animal model of early-onset obesity. Horm Behav. Elsevier Inc.; 2010 Apr;57(45):496-505.

9. Patterson CM, Bouret SG, Dunn-Meynell AA, Levin BE. Three weeks of postweaning exercise in DIO rats produces prolonged increases in central leptin sensitivity and signaling. Am J Physiol Regul Integr Comp Physiol. 2009 Mar;296(3):R537-48.

10. Fernandes R a, Zanesco A. Early physical activity promotes lower prevalence of chronic diseases in adulthood. Hypertens Res. 2010 Sep;33(9):926-31.

11. de Moura LP, Sponton AC da S, de Araújo MB, Dalia RA, Pauli JR, Rostom de Mello MA. Moderate physical activity from childhood contributes to metabolic health and reduces hepatic fat accumulation in adult rats. Lipids Health Dis. 2013;12:29.

12. Jones AM, Doust JH. The validity of the lactate minimum test for determination of the maximal lactate steady state. Med Sci Sports Exerc. 1998 Aug;30(8):1304-13.

234 • Rev Bras Educ Fís Esporte, (São Paulo) 2020 Abr-Jun;34(2):227-36 
13. Engel PC, Jones JB. Causes and elimination of erratic blanks in enzymatic metabolite assays involving the use of NAD+ in alkaline hydrazine buffers: improved conditions for the assay of L-glutamate, L-lactate, and other metabolites. Anal Biochem. 1978 Aug 1;88(2):475-84.

14. Bonora E, Moghetti P, Zancanaro C, Cigolini M, Querena M, Cacciatori V, et al. Estimates of in vivo insulin action in man: comparison of insulin tolerance tests with euglycemic and hyperglycemic glucose clamp studies. J Clin Endocrinol Metab. 1989 Feb;68(2):374-8.

15. Lundbaek K. Intravenous glucose tolerance as a tool in definition and diagnosis of diabetes mellitus. Br Med J. 1962 Jun 2;1(5291):1507-13.

16. Herbert V, Lau KS, Gottlieb CW, Bleicher SJ. Coated charcoal immunoassay of insulin. J Clin Endocrinol Metab. 1965 Oct;25(10):1375-84.

17. Matthews DR, Hosker JP, Rudenski AS, Naylor BA, Treacher DF, Turner RC. Homeostasis model assessment: insulin resistance and beta-cell function from fasting plasma glucose and insulin concentrations in man. Diabetologia. 1985 Jul;28(7):412-9.

18. Malaisse WJ, Malaisse-Lagae F, Wright PH. Effect of fasting upon insulin secretion in the rat. Am J Physiol. 1967 Oct;213(4):843-8.

19. Robinson AM, Williamson DH. Control of glucose metabolism in isolated acini of the lactating mamary gland of the rat. Effects of oleate on glucose utilization and lipogenesis. Biochem J. 1978 Mar 15;170(3):609-13.

20. Sjörgreen B, Nordenskjold T, Holmgren H, Wollerstrom J. Bertrag zur kentnis des le berrhythmik. Pfluger Arch Gesante Physiol Menschen Tiere. 1938;240-7.

21. Dubois M, Gilles K, Hamilton J, Rebers P, Smith F. Colorimetric method for determination of sugars and related substances. Anal Chem. 1956;28(3):350-6.

22. de Mello MA, de Souza CT, Braga LR, dos Santos JW, Ribeiro IA, Gobatto CA. Glucose tolerance and insulin action in monosodium glutamate (MSG) obese exercise-trained rats. Physiol Chem Phys Med NMR. 2001;33(1):63-71.

23. Cinti S, Mitchell G, Barbatelli G, Murano I, Ceresi E, Faloia E, et al. Adipocyte death defines macrophage localization and function in adipose tissue of obese mice and humans. J Lipid Res. 2005 Nov;46(11):2347-55.

24. Hashimoto T, Sato K, Iemitsu M. Exercise-inducible factors to activate lipolysis in adipocytes. J Appl Physiol. 2013 Jul 15;115(2):260-7.

25. Dimitriadis G, Mitrou P, Lambadiari V, Maratou E, Raptis SA. Insulin effects in muscle and adipose tissue. Diabetes Res Clin Pract. 2011 Aug;93 Suppl 1:S52-9.

26. Ma ZA. The role of peroxidation of mitochondrial membrane phospholipids in pancreatic $\bigotimes$-cell failure. Curr Diabetes Rev. 2012 Jan;8(1):69-75.

27. de Moura LP, Souza Pauli LS, Cintra DE, de Souza CT, da Silva ASR, Marinho R, et al. Acute exercise decreases PTP-1B protein level and improves insulin signaling in the liver of old rats. Immun Ageing. 2013;10(1):8.

28. Janiszewski PM, Ross R. The utility of physical activity in the management of global cardiometabolic risk. Obesity (Silver Spring). 2009 Dec;17 Suppl 3:S3-14.

29. Pauli JR, Ropelle ER, Cintra DE, De Souza CT, da Silva ASR, Moraes JC, et al. Acute exercise reverses aged-induced impairments in insulin signaling in rodent skeletal muscle. Mech Ageing Dev. 2010 May;131(5):323-9.

30. Ropelle ER, Flores MB, Cintra DE, Rocha GZ, Pauli JR, Morari J, et al. IL-6 and IL-10 anti-inflammatory activity links exercise to hypothalamic insulin and leptin sensitivity through IKKbeta and ER stress inhibition. PLoS Biol. 2010 Aug 24;8(8):31-2.

31. Jessen N, Goodyear LJ. Contraction signaling to glucose transport in skeletal muscle. J Appl Physiol. 2005 Jul;99(1):330-7.

32. Witczak CA, Fujii N, Hirshman MF, Goodyear LJ. Ca2+/calmodulin-dependent protein kinase kinase-alpha regulates skeletal muscle glucose uptake independent of AMP-activated protein kinase and Akt activation. Diabetes. 2007 May;56(5):1403-9.

33. Rimbert V, Boirie Y, Bedu M, Hocquette J-F, Ritz P, Morio B. Muscle fat oxidative capacity is not impaired by age but by physical inactivity: association with insulin sensitivity. FASEB J. 2004 Apr;18(6):737-9.

34. Roach PJ. Glycogen and its metabolism. Curr Mol Med. 2002 Mar;2(2):101-20.

35. Romijn JA, Coyle EF, Sidossis LS, Gastaldelli A, Horowitz JF, Endert E, et al. Regulation of endogenous fat and carbohydrate metabolism in relation to exercise intensity and duration. Am J Physiol. 1993 Sep;265(3 Pt 1):E380-91.

36. Matsui T, Ishikawa T, Ito H, Okamoto M, Inoue K, Lee M-C, et al. Brain glycogen supercompensation following exhaustive exercise. J Physiol. 2012 Feb 1;590(3):607-16. 
Pereira RM, et al.

37. Pinho CA, Tromm CB, Tavares AM V, Silva LA, Silveira PCL, Souza CT, et al. Effects of different physical training protocols on ventricular oxidative stress parameters in infarction-induced rats. Life Sci. 2012 Apr 9;90(13-14):553-9.

38. Johannsen NM, Swift DL, Johnson WD, Dixit VD, Earnest CP, Blair SN, et al. Effect of different doses of aerobic exercise on total white blood cell (WBC) and WBC subfraction number in postmenopausal women: results from DREW. PLoS One. 2012;7(2):e31319.

39. Nyberg M, Jensen LG, Thaning P, Hellsten Y, Mortensen SP. Role of nitric oxide and prostanoids in the regulation of leg blood flow and blood pressure in humans with essential hypertension: effect of high-intensity aerobic training. J Physiol. 2012 Mar 15;590(6):1481-94.

40. Dubé JJ, Allison KF, Rousson V, Goodpaster BH, Amati F. Exercise dose and insulin sensitivity: relevance for diabetes prevention. Med Sci Sports Exerc. 2012 May;44(5):793-9.

CORRESPONDING AUTHOR

Rodrigo Martins Pereira

Rua Pedro Zaccaria, 1300

13083-872 - Limeira - SP - BRAZIL

E-mail: rodrigo_mpereira@hotmail.com
Submitted: 18/07/20171a.

1st. Review: 02/03/2018

Accepted: 11/07/2018

236 • Rev Bras Educ Fís Esporte, (São Paulo) 2020 Abr-Jun;34(2):227-36 